Nat. Hazards Earth Syst. Sci. Discuss., doi:10.5194/nhess-2016-231, 2016

Manuscript under review for journal Nat. Hazards Earth Syst. Sci.

Published: 2 August 2016

(C) Author(s) 2016. CC-BY 3.0 License.

(c) (i)
Natural Hazards

and Earth System

Sciences

Discussions

\title{
Lightning risk assessment at a high spatial resolution using the resident sub-district scale: A case study in Beijing metropolitan areas
}

\author{
HaiBo $\mathrm{Hu}^{1}$, JingXiao $\mathrm{Li}^{2}$
}

$5 \quad{ }^{1}$ Institute of Urban Meteorology, CMA, Beijing, 100089, China

${ }^{2}$ Beijing Lightning Devices Security Test Center, Beijing, 100080, China

Correspondence to: HaiBo Hu (hbhu@ium.cn)

\begin{abstract}
Lightning risk indexes identifying the potential number of dangerous lightning events (NDLEs) and ground sensitivity to lightning in resident sub-districts of Beijing metropolitan areas have been unprecedentedly estimated on a $5 \mathrm{~m}$ resolution grid. The gridded cloud to ground (CG) lightning stroke density was used in the NDLE calculation, on account of multiple contacts formed by CG lightning flash multiplicity. Meanwhile, in the NDLE estimates, the critical CG stroke gridded densities derived from the lightning location system (LLS) data were corrected for network detection efficiency (DE). This case study on resident sub-district indicates that the site-specific sensitivity to lightning, which is determined by the terrain factors related to lightning attachment, as well as lightning rod effects induced by nearby structures, differs

15 greatly across types of underlying ground areas. The discrepancy of the NDLE which is the numerical product of sensitivity and CG stroke density, is predominated by the sensitivity on account of the relatively stationary CG stroke density in a resident sub-district scale. Conclusively, the visualization of lightning risk sensitivity and NDLE discrepancy in parts of a resident sub-district at high spatial resolution makes it convenient in risk reduction and risk control for lightning risk management.
\end{abstract}

\section{Introduction}

The frequent occurrences of lightning disaster events cause large numbers of casualties and substantial damage losses, such that lightning is considered as one of the most dangerous natural hazards (Curran et al. 2000; Holle et al. 2005; Zhang et al. 2011) and second meteorological killer (Ashley and Gilson 2009). Lightning risk assessment is meant to investigate, search for and locate high-risk areas, enabling the implementation of mitigation measures for lightning risk reduction (Kaplan and

25 Garrick 1981; Hu et al. 2014). It is desirable to assess lightning risks at an extremely high resolution (e.g., $5 \mathrm{~m}$ spacing grid), sufficiently detailed in reflecting lightning risk characteristics and allowing risk discrepancies recognizable in a real-world view. This recognition makes it applicable for disaster preparedness and delivers a practical lightning risk management (Mills et al 2010). 
Nat. Hazards Earth Syst. Sci. Discuss., doi:10.5194/nhess-2016-231, 2016

Manuscript under review for journal Nat. Hazards Earth Syst. Sci.

Published: 2 August 2016

(C) Author(s) 2016. CC-BY 3.0 License.
Natural Hazards

and Earth System

Sciences

Discussions

(c) (i)

At a high spatial resolution, it is possible of deliberately locating specific underlying areas especially in densely populated urban areas, and improving the estimates of ground sensitivity to lightning, which is correlated to certain environmental settings, such as topographical features and distribution of earthed structures (Rizk 1994; Vogt 2011). Approaches will be employed to finish the pattern recognition of topographical features, locating and determining the lightning collection areas

5 of earthed structures, downscaling CG stroke density into a finer grids, etc. Undoubtedly, it can be fulfilled with GIS technology supported by high resolution mappery-data.

Natural lightning strokes on the ground are obvious drivers of lighting-related disasters. Lightning climatology, preliminarily manifesting lightning risk, should be described quantitatively for risk assessment (Bogdan and Burcea 2010). The approach is to derive lightning parameters (e.g., CG flash/stroke density, CG flash multiplicity) from observational data, e.g.,

10 climatological data (Changnon 1985; Gabriel and Changnon 1989), satellite sensing lightning imagery ( Christian et al. 2003) and lightning location system (LLS) data (Changnon 1993; Schulz et al. 2005; Biagi et al. 2007; Cummins et al. 2009). These lightning parameters fundamentally reflect regional lightning activity relevant to lightning disaster occurrence (Schulz et al. 2005; Mäkelä et al. 2010). They are critical in confirming lightning risk even at a resident sub-districts scale. As a premise of risk recognition, lightning characteristics should be unveiled mostly by introducing LLS data, on account of its

15 high spatial-temporal resolution (e.g., Krider et al. 1980). Then the lighting risk characteristics would be revealed by overlapping the lightning characteristics (CG flash/stroke density) with other risk factors (e.g., sensitivity and exposure) (Hu 2014).

Lightning risk is linked to the combined effects of regional lightning activities and ground sensitivity to lightning, reflecting on-site lightning hazards. Risk recognition at high resolution can visualize the decision-making procedures in risk

20 management. It facilitates the formulation of practical risk management strategies for disaster prevention (Smith 1996). For a resident sub-district, the visualized lightning risk recognition can provide information in a form that is straightforwardly understandable to local decision and policy makers. Moreover, this quantitative information about site-specific lightning risk is critical to public safety and infrastructure planning (Stallins and Rose 2008).

\section{Data description}

\section{$25 \quad 2.1$ Lightning location system (LLS) data}

The LLS data collected from 2007-2011 by the ADTD (Advanced TOA and Direction system; TOA denotes time-of-arrival) network deployed by the China Meteorology Administration (CMA) were used to derive the CG flash/stroke density. These data include time, location, amperage and polarity of CG lightning strokes.

The ADTD consists of more than 301 sensors (by March, 2011) in China (Yao et al. 2012). Around Beijing district, nearly 9-

3014 ADTD-1 sensors, types of improved IMPACT (combined MDF and time-of-arrival (TOA)) sensors, detect 1 k-450 kHz (the very low frequency (LF) band) lightning sources (Fig. 1). The ADTD-1 sensors use the combined MDF and time-ofarrival (TOA) method for position retrieval. In this method, if lightning source is only detected by two ADTD-1 sensors, the 
Nat. Hazards Earth Syst. Sci. Discuss., doi:10.5194/nhess-2016-231, 2016

Manuscript under review for journal Nat. Hazards Earth Syst. Sci.

Published: 2 August 2016

(C) Author(s) 2016. CC-BY 3.0 License.
Natural Hazards

and Earth System

Sciences

Discussions

(c) $\underset{\mathrm{BY}}{\mathrm{BY}}$

algorithm uses one TOA hyperbolic curve and two MDF vectors to retrieve the position; if it is detected by three sensors, in non-bilingual region, the TOA algorithm is used to retrieve the position directly, whereas the TOA is firstly used to find a bilingual locations and then using the MDF to find the true location; if it is detected by four or more sensors, a TOA least square method is used to retrieve a more precise position. So the location precision of the lightning resource reported by four

5 or more sensors is actually better than that reported by two or three sensors. In our LLS data, the ratio of four or more sensors reporting lightning resources to the total is $66.815 \%$.

The DE of ADTD sensors is claimed to be $90 \%$ in $300 \mathrm{~km}$, with a $600 \mathrm{~km}$ maximum detectable distance, and a location accuracy error within $1 \mathrm{~km}$. However, $90 \%$ of the flash DE can be validated, but with a lower stroke detection efficiency (SDE). The first stroke peak current in a multiplicity CG flash can be greater than twice of its subsequent stroke peak current

10 (Rakov and Uman 1990); thus, the sensors can capture the first larger peak stroke but missing its weak subsequent (Rudlosky and Fuelberg 2010). Moreover, some weak CG strokes (including a single-stroke CG flash) cannot be detected due to signal attenuation induced by long distance propagation and terrain factors (Schütte et al. 1988), etc., .

The stroke number is critical in lightning risk estimates (Bertram and Mayr 2004). Thus, we estimated the SDEs of the ADTD in grids ( $1 \mathrm{~km} \times 1 \mathrm{~km}$ size, see Fig. 1) around Beijing and corrected the lightning stroke density for network DE. The

15 SDE estimates approximate those of the U.S. NLDN (National Lightning Detection Network) in 1998, which was reported to be 62\% (Idone et al. 1998). So the DE level of ADTD is equivalent to that of the NLDN at least in 1998, indicating a great improvement left for network upgrades.

\subsection{Others}

Digital elevation model (DEM) data were used to identify site-specific lightning attachment capabilities on account of the

20 topography (Vogt 2011). Its $30 \mathrm{~m}$ spatial resolution basically meets the need of identifying hypsographic features and confirming terrain factors.

Additionally, the basic GIS data with map scales of 1:2000 in urban settings and 1:50,000 in rural settings have been used to measure a structure's lighting collection area, incorporating the structure's geometric shape and height, which are readily available in GIS map layers (Hu et al. 2014). The dataset of GIS map-layer keeps the structure-type field which can be used

25 to determine the structure lightning protection capability.

\section{Methods}

The lightning risk index of the potential number of dangerous lightning events (NDLE) is preserved for lightning risk zoning at a resident sub-district scale. Correlated to regional lighting activity and sensitivity to lightning at a site, the NDLE $N_{x}$ can generally be estimated as (Hu et al. 2014)

$30 \quad N_{x}=K \times N_{g} \times A_{d}$, 
Nat. Hazards Earth Syst. Sci. Discuss., doi:10.5194/nhess-2016-231, 2016

Manuscript under review for journal Nat. Hazards Earth Syst. Sci.

Published: 2 August 2016

(C) Author(s) 2016. CC-BY 3.0 License.

(c) (i)
Natural Hazards

and Earth System

Sciences

Discussions

where $K$ denotes the coefficient related to environmental settings onsite; $N_{g}$ the CG lightning stroke density (stroke/yr.km²); and $A_{d}$ the collection area of the lightning strike, mostly determined by site-specific lightning attractiveness variably in types of underlying ground areas. On account of each stroke in a multiple-stroke CG flash can produce damage losses and/or casualties, it is reasonable of taking $N_{g}$ to be the CG stroke density (stroke/yr.km²).

\section{3.1 CG lightning stroke density corrected for DEs and downscaling}

The CG stroke density $N_{g}^{\prime}$ derived from LLS data was corrected for DEs of the ADTD using the following equation. $N_{g}=\frac{N_{g}^{\prime}}{D_{g}}$

where $N_{g}$ is the corrected CG stroke density; $D_{g}$ the DE in grids.

The CG stroke density in the $5 \mathrm{~m}$ grids had been downscaled from $1 \mathrm{~km}$ grids. We used the approach of inverse distance

10 weighting (IDW) to interpolate the CG stroke density from these of the larger grids ( $1 \mathrm{~km}$ spaced), which 9 grid cells were involved, including the containing, up, down, up-left, up-right, left, right, down-left, and down-right $1 \mathrm{~km} \times 1 \mathrm{~km}$ grid-cell. Mathematically, the interpolation can be described as

$$
N_{g 5 m}=\sum_{i=1}^{n} N_{g}(i) \cdot \frac{1 / r(i)}{\sum_{n=1}^{n} 1 / r(i)},
$$

where $N_{g 5 m}$ is the interpolated CG stroke density in $5 \mathrm{~m}$ spaced gridcell; $n(n \leq 9)$ the number of the containing and its

15 around $1 \mathrm{~km}$ spaced grid-cells; $N_{g}(i)$ the CG stroke density of the $i$ th $1 \mathrm{~km}$ spaced grid-cell; $r(i)$ the distance of the center point of the $5 \mathrm{~m}$ gridcell to that of the $i$ th $1 \mathrm{~km}$ spaced grid-cell.

\subsection{NDLE estimates in $5 \mathrm{~m}$ spacing grids}

We calculated the NDLEs on earthed structure, outdoor area under a structure canopy and an open-field area, respectively, on account of difference in estimating their lightning protection capability, lightning attachment and lightning attractiveness.

20 The approaches are correspondently adjusted in conditions of the grids intersecting on different types of underlying areas (Fig. 2).

\subsubsection{NDLE estimates of an earthed structure (ES)}

The NDLEs of a structure $N_{d}$ is calculated as (Hu et al. 2014):

$$
N_{d}=N_{g} \cdot A_{d} \cdot C_{d} \cdot P_{d} \cdot 10^{-6},
$$

25 where $A_{d}\left(\mathrm{~m}^{2}\right)$ is the collection area of a structure to lightning; $C_{d}$ the terrain factor, which is deduced using DEM data, accounting for its relationship to the surrounding topography (see Table1); $P_{d}$ is the coefficient representing the lightning protection capability of the structure. 
Nat. Hazards Earth Syst. Sci. Discuss., doi:10.5194/nhess-2016-231, 2016

Manuscript under review for journal Nat. Hazards Earth Syst. Sci.

Published: 2 August 2016

(c) Author(s) 2016. CC-BY 3.0 License.

Given the structure height in meters $H$, the collection area $A_{d}$ can be determined as (Rizk 1994)

$A_{d}=670.8 \pi H^{0.96}$,

The structure protection capability includes these of protecting 1) the live beings from injured by a lightning stroke, 2) the structure from physical damage, and 3) the internal systems in the structure. Substantially, these capabilities are represented

5 by the casualty probability $p_{a}$, the physical damage probability $p_{b}$, and the internal systems failure probability $p_{c}$, respectively in risk estimates. Herein, for simplification, only $p_{a}$ is taken into account of the lightning risk assessment, i.e., $P_{d}=p_{a}$.

The casualty probability due to touch and step voltage induced by a lightning stroke to the structure, reflects the structure Lightning Protection Level (LPL), which can be determined according to the lightning protection measures taken by a structure (Table 2).

10 We have defined the protection measures that would be probably taken by 10 structure types in Beijing (see Table 2), readable in a GIS map-layer dataset. Most structures are equipped with lightning rods. Some concrete steel structures have iron infra-structure and framework as the lead-in wire for lightning protection. Thus they possess a better capability of protecting the live beings from injured by ground lightning stroke.

\subsubsection{NDLE estimates of an outdoor area under a structure canopy (OAUSC)}

15 Under this condition, the NDLEs $N_{d c}$ can be calculated as

$N_{D c}=N_{g} \cdot A_{D c} \cdot C_{d} \cdot C_{c} \cdot 10^{-6}$,

where $A_{D c}\left(\mathrm{~m}^{2}\right)$ is the intersection area of the OAUSC and the grid cell; $C_{d}$ the terrain factor of the grid cell; and $C_{c}$ the coefficient representing lightning rod effects produced by the surrounding structures. At a fine grid scale (e.g., $5 \mathrm{~m}$ ), its calculation is simplified as follows (Petrov and D' Alessandro 2002):

20

$C_{c}=\frac{1}{\sum_{i=1}^{n} H(i)}$,

where $H(1), \ldots, H(n)$ are the floor numbers of the surrounding structures, whose canopies cover the grid cell. It is conceivable that $C_{c}$ will approximate zero if the grid cell is under canopies of many nearby tall structures.

\subsubsection{NDLE estimates of an outdoor area under a structure canopy (OAUSC)}

Totally exposed to lightning stroke, open-field area is more susceptible to lightning. Thus, its NDLEs $N_{D s}$ can be estimated 25 as

$N_{D s}=N_{g} \cdot A_{D s} \cdot C_{d} \cdot 10^{-6}$,

where $A_{D s}$ is the intersection area of the OFA and the grid cell. 
Nat. Hazards Earth Syst. Sci. Discuss., doi:10.5194/nhess-2016-231, 2016

Manuscript under review for journal Nat. Hazards Earth Syst. Sci.

Published: 2 August 2016

(c) Author(s) 2016. CC-BY 3.0 License.

\subsubsection{NDLE estimates of an outdoor area under a structure canopy (OAUSC)}

After the NDLEs of the three types of underlying ground areas are calculated out, the NDLEs of a grid cell intersecting with these areas, $N d \_C e l l$, can be calculated as

$$
\begin{aligned}
& N d_{-} \text {Cell }=N_{d} \times \text { Inter } \sec t(\text { Area_Cell, Area_ES }) \\
& +N_{D c} \times \text { Inter } \sec t(\text { Area } C \text { Cell, Area_OAUSC }) \\
& +N_{D S} \times \text { Inter } \sec t(\text { Area } C \text { Cell, Area_OFA })
\end{aligned}
$$

5 where Area_Cell, Area_ES, Area_OAUSC, and Area_OFA denote the geometries of the grid cell, earthed structure, outdoor area under structure canopy and open-field area in the grid cell, respectively, and Intersect is a GIS operator of calculating the intersection areas of the grid cell and the geometries of the three types of underlying ground areas (i.e., the structure, outdoor area under structure canopy and open-field area), respectively.

\subsection{Parameters reflecting lightning risk characteristic}

10 The lightning risk assessment follows the workflow of 1) estimating NDLEs and sensitivity, 2) searching out high risk areas, and then 3) providing pertinent advice for decision makers who will take measures addressing lightning risk mitigation in the resident sub-district.

The CG stroke density, $N_{g}$, ground sensitivity to lightning, $S_{x}$, and NDLEs, $N_{d}$, essentially reflect the lightning risk characteristics in a local community with respect to decision making in lightning risk management. The CG stroke density,

$15 N_{g}$, which is an indicator of regional lightning activity, can be derived from the LLS data. The NDLEs, a numerical product of the CG stroke density $N_{g}$ and sensitivity $S_{x}$, reflect the lightning hazardousness at a site. In definition, the sensitivity is an indicator of proneness to lightning strike, comprehensively measured by underlying ground lightning attractiveness, lightning protection, and lightning attachment, correlated to land-surface characteristics, e.g., terrain features and existence of earthed structures. Accounting for site-specific environmental settings rather than regional lightning activity, it can be calculated as

$$
\begin{aligned}
& S_{\mathrm{d}}=A_{d} \bullet C_{d} \bullet P \bullet 10^{-6}, \\
& S_{\mathrm{Dc}}=A_{D c} \bullet C_{d} \bullet 10^{-6}, \\
& S_{D S}=A_{D S} \bullet C_{d} \bullet 10^{-6},
\end{aligned}
$$

where $S_{d}, S_{D c}$, and $S_{D s}$ denote the sensitivity to lightning on a structure, outdoor area under a structure canopy and open-field area, respectively. The discrepancy of NDLEs in a sub-district is mostly determined by that of the sensitivity, due to the relatively stationary CG stroke density. In this context, the sensitivity and the NDLEs jointly describe the lightning risk characteristics at a high resolution. 
Nat. Hazards Earth Syst. Sci. Discuss., doi:10.5194/nhess-2016-231, 2016

Manuscript under review for journal Nat. Hazards Earth Syst. Sci.

Published: 2 August 2016

(c) Author(s) 2016. CC-BY 3.0 License.
Natural Hazards

and Earth System

Sciences

Discussions

\section{Analysis on lightning characteristics}

Lightning climatology preliminarily reflects lightning risk, not accounting for the sensitivity and exposure to lightning (Ashley and Gilson 2009). Analysis on lightning characteristics is the premise of risk assessment even in a sub-district, at lest it can provide the critical parameters for lightning risk assessment, e.g., the CG flash/stroke density and CG multiplicity.

5 We derived the lightning parameters from the ADTD data by counting the annual CG flash/stroke numbers at a resolution of $1 \mathrm{~km}$. The CG strokes were grouped into flashes based on a multiplicity delay of $1 \mathrm{~s}$ within a radius of $20 \mathrm{~km}$ (Cummins et al., 2006, Drüe et al. 2007) and +CG flashes with a peak current of less than $15 \mathrm{kA}$ were classified as IC lightning (recommended by Cummins and Murphy 2009).

Convection events are usually enhanced by orographic uplift in the mountains, which trigger more CG strikes (Bourscheidt

10 et al. 2009). However, the derivation from the ADTD data exhibits a relatively lower CG flash/stroke densities in the north and west mountainous areas than that in the plains, except for a relative high density in the south-west mountains (Fig. 3). Cummins et al. (2006) suggested that an elevated terrain and conductivities of the underlying surface have a stronger influence on the attenuation of the signal produced by CG flashes, in turn reducing the network DE. Moreover, the thunderstorms in urban areas on the plains can be enhanced by urban characteristics (e.g., roughness, aerosols, and urban

15 heat islands) and consequently induce more CG flashes (Shepherd et al. 2002; Rose et al. 2008; Stallins and Rose 2008; Hu et al 2014, 2015; Kar and Liou 2014), e.g., the downwind areas having high CG stroke densities (see the blue-circled in Fig 3.c). Also, a high CG stroke density distributed in upwind southern areas (see the purple-circled in Fig 3.c) can be perceived. We assumed that it should be related to random cloud condensation nuclei $(\mathrm{CCN})$ concentrations affecting the clouds over cities (Steiger et al. 2002; Stallins et al. 2006; Kar and Liou 2014).

20 No matter what can explains the higher CG flash/stroke density in the plains, the DE of a LLS cannot be 100\% (Schulz et al. 2005; Mazarakis et al. 2008). The actual CG stroke numbers in the grids, however, are required in the NDLE estimates. Thus, we corrected the grided CG stroke densities for DEs to fit the actual.

Network DE is determined by the performance and sensitivity of sensors, the sensor network geometry, and the underlying ground conductivity (Schütte et al. 1988; Naccarato and Pinto 2009; Mäkelä et al. 2010), etc., . The capability of DE estimates in correcting CG flashes/strokes and evaluating the LLS network performance invoked a series of methodologies published in the literature (e.g., Schütte et al. 1988; Cummins et al. 1998; Naccarato and Pinto 2009). Although DE can be determined more precisely with observations collecting exact information of lightning occurrences (e.g., video or tower measurements), this approach can only be experimentally utilized in producing localized DE estimates (Saraiva et al. 2010; Visacro et al. 2010; Warner et al. 2013). The methods of DE estimates using theoretical models are more convenient and

30 applicable in comprehensively confirming a network DE. Schütte et al. (1987, 1988) introduced the Weibull-distribution into sensors' signal strength acceptance estimates, facilitating network DE calculations. Cummins et al. (1998) also combined the peak current cumulative distribution with a signal-propagating model to estimate the absolute flash DE for the NLDN. 
Nat. Hazards Earth Syst. Sci. Discuss., doi:10.5194/nhess-2016-231, 2016

Manuscript under review for journal Nat. Hazards Earth Syst. Sci.

Published: 2 August 2016

(C) Author(s) 2016. CC-BY 3.0 License.
Natural Hazards

and Earth System

Sciences

Discussions

(c) (i)

Naccarato and Pinto (2009) deduced the DE values using the sensor's individual DE probability functions derived from a large network detected CG stroke data, considering different distances from the sensors and specific peak current ranges.

We calculated the DEs of the ADTD in raster grids according to the networks performance and sensitivity measured by the distances and azimuths among sensors.

5 Methodologically, in case of the weibull distribution of signal strength (Schutte et al. 1987), the signal acceptance of a sens or can be given by

$A(r)=\left\{\begin{array}{ll}0 & r<c r_{0} / s_{\max } \\ 1-\exp \left[-\left(\frac{s_{\max } r / r_{0}-c}{a}\right)^{b}\right] & c r_{0} / s_{\max }<r \leq c r_{0} / s_{\min } \\ \exp \left[-\left(\frac{s_{\min } r / r_{0}-c}{a}\right)^{b}\right]-\exp \left[-\left(\frac{s_{\max } r / r_{0}-c}{a}\right)^{b}\right] & r>c r_{0} / s_{\min }\end{array}\right.$,

where $s_{\min }$ and $s_{\max }$ are the lower and upper signal threshold, which will be 20 and 600 arbitrary units (a. u.), respectively; $r_{0}$ the standard distance, which will be $100 \mathrm{~km} ; r$ the distance to the sensor; $a, b$, and $c$ are the scale, the shape and the location

10 parameter of the Weibull distribution of signal strength (Schütte et al. 1987, 1988).

Only two ADTD IMPACT sensors reporting a stroke are required to get a valid solution. Thus, the DE on a grid-cell can be determined as (Naccarato and Pinto 2009)

$A=A_{1}\left(r_{1}\right) \times A_{2}\left(r_{2}\right) \quad A_{1}$ ranked $\quad A_{1}\left(r_{1}\right) \geq A_{2}\left(r_{2}\right) \geq A_{3}\left(r_{3}\right) \geq \ldots$

where $A_{i}\left(r_{i}\right)$ denotes the acceptance of one sensor; $r_{i}(\mathrm{i}=1,2,3, \ldots)$ is the distance of the $i$ th nearest sensor to the grid-cell

15 center and $A$ the grid-cell DE of the network.

After corrected using these deduced DEs (see Fig. 1), the CG stroke densities in the northeast mountains, metropolitan areas, south plains and southwest mountains increased significantly in comparison with the uncorrected CG stroke densities (see Fig. 3b-c). The corrected densities in metropolitan areas are mainly between 4-6 stroke/yr.km², which is higher than expected. However, the relatively high CG stroke density remains in the plains. It is advisable that the network should be

20 upgraded for improvement of the network DE and detection accuracy. Maybe this anomaly can be explained using observed evidence.

\section{Case study of lightning risk assessment in a resident sub-district}

The model running out at a $5 \mathrm{~m}$ resolution optimally covers a small area of $10-100 \mathrm{~km}^{2}$. We selected two resident subdistricts in Beijing metropolitan areas for risk analysis on the indicators of sensitivity and NDLEs. One selected is the subdistrict of Malianwa located in the northwest metropolitan areas and foothills of the western YanShan Range. Its complex topography implies a diversity of ground sensitivity to lightning. The other is Beijing International Airport, where the lightning risk discrepency is remarkable between the open fields of the aircraft parking areas and the terminal structure inside. 
Nat. Hazards Earth Syst. Sci. Discuss., doi:10.5194/nhess-2016-231, 2016

Manuscript under review for journal Nat. Hazards Earth Syst. Sci.

Published: 2 August 2016

(c) Author(s) 2016. CC-BY 3.0 License.
Natural Hazards

and Earth System

Sciences

Discussions

\subsection{Ground sensitivity to lightning}

Sensitivity recognition contributes to lighting risk avoidance on thunderstorm days, in respect to risk management. Also, it can be used in directing deployment of lightning protection facilities and systems (Schulz et al. 2005).

The lightning sensitivity zoning in the sub-district of Malianwa indicates that the sensitivities of structures and outdoor areas

5 under structure canopies are usually less than 0.15 in magnitude (Fig. 4a). Alternatively, if not accounting for the terrain factors, the greatest sensitivity is 1.0 on an open field in the plains (Fig. 4a). Accounting for the terrain factors, the sensitivity in mountainous areas will increase to 1.15-1.3, which occurs, for example, in the western uplands of this sub-district (see $A$ in Fig. 4b-c), where the high sensitivity zones spread. This higher sensitivity in the hills means that the CG strikes would favor topographic highpoints by as much as $15-30.0 \%$ when compared with random points in the plains. This increased

10 sensitivity of topographic highpoints is somewhat in agreement with the findings of Vogt (2011).

Displayed in Google Earth, the sensitivity zones exhibit a good correlation with topographical features and distribution of earthed structures (see Fig. 4c). Apparently, the simulated sensitivity is explicably in accordance with the settings and it merits visualization in lightning risk management.

\subsection{NDLES}

15 Similar to sensitivity, NDLEs on a structure and an outdoor area under structure canopy are lower, while the NDLEs on an open-field area are equal or even magnitudes greater than the CG stroke densities of the downscaled grids. NDLEs of the uplands in western Malianwa exhibit this pattern where more upward and/or downward lightning can be triggered on account of topographic highpoint attachment (Warner et al. 2013).

The advantage of quantitative risk assessment at high resolution is that its visualized risk characteristics can play an

20 important role in operating risk control effectively. For instance, at Beijing International Airport, terminal 3 (a 45 meter high structure) and its nearby outdoor areas under structure canopies exhibit a low assessed sensitivity of 0.15 , equivalent to 0.15 times that of an open-field area, and NDLEs below 0.5 (time/yr.km²) (Fig. 6). Conversely, the red-ellipse in the aircraft parking apron, hundreds of meters away from the terminal, exhibit a high sensitivity of 1.0, and NDLEs above 2.5 (time/yr.km²) (Fig. 6), due to the lack of lightning protection and structure shelter. On Aug. 11th, 2013, a lightning fatality

25 occurred exactly within the red-ellipse (Fig. 6b), wherein a cleaning staff member was struck dead by lightning when using a mobile phone (Hu 2014). Therefore, the personnel should pay attention to lightning on thunderstorm days when operating in open fields. Moreover, lightning risk management should be conducted based upon risk recognition in the airport community so that it can visually inform where is safe or not (Fig. 6).

\section{Conclusion}

30 The DE of a lightning location system (LLS) cannot be $100 \%$ and low DE are usually due to lack of deployed network sensors, as well as the performance and sensitivity of sensors. Meanwhile, the signals produced by CG flashes can be 
Nat. Hazards Earth Syst. Sci. Discuss., doi:10.5194/nhess-2016-231, 2016

Manuscript under review for journal Nat. Hazards Earth Syst. Sci.

Published: 2 August 2016

(c) Author(s) 2016. CC-BY 3.0 License.
Natural Hazards

and Earth System

Sciences

Discussions

(c) $\underset{\mathrm{BY}}{\mathrm{B}}$

strongly attenuated by long distance propagation, terrain factors and underlying conductivity. Before being used in NDLE estimates, the CG stroke densities derived from LLS data could be corrected for DEs. Although the correction of CG stroke density makes it better qualified for risk assessment, it is preferable that the LLS data should be more reliable with the network upgrading to improve the DE and location accuracy (Rudlosky and Fuelberg 2010). Moreover, network upgrades

5 should be implemented not only for optimal lightning location in the metropolitan areas but also in the mountainous rural areas, where more lighting casualties occur (López and Holle 1998; Curran et al. 2000; Zhang et al. 2011).

The uncertainty of lightning risk estimates at this high resolution will be induced by the LLS data quality related to location precision, and imperfect network DEs. Also, the model structures and operations (e.g., CG stroke density downscale) magnify this uncertainty. Though the IDW interpolation and the overlapping of derived CG stroke density with the ground

10 sensitivity to lightning somehow attenuate the errors of risk estimate, the uncertainty remains. However, it can be suggested the uncertainty caused by LLS data quality should be reduced by network upgrades with adding and/or replacing a higher performance and sensitive sensors. Moreover, further research can be undertaken to evaluate the reliability of this risk estimates in uncertainty (e.g., Monte Carlo simulation), or even to find an effective approach of uncertainty reduction leading to more precise calibration and correction.

15 The model running at a fine resolution (e.g., $5 \mathrm{~m}$ grids) enables lightning risk assessment accessibly accounting for the ground sensitivity of the types of underlying ground areas, as well as overlapped with CG stroke density. The lightning risk recognition at high resolution can reveal risk discrepancies visually and locate higher risk areas at a finer scale, making it favorable in lightning risk management.

This case study indicates that the lightning rod effects of structures make low risk in an outdoor area under its canopy. In

20 comparison, an open field area usually exhibits a higher risk, with its NLDE equal to the corresponding CG stroke density and its sensitivity nearly 1.0 in magnitude. On account of terrain factors, NLDEs and sensitivity can increase by 1.15-1.3 times in uplands vs. the plains due to higher lightning attachment in elevated areas.

The distributions of lightning parameters (e.g., CG flash/stroke density), ground sensitivity to lightning and NDLE comprehensively reveal lightning risk characteristics. The CG lightning flash/stroke density, CG flash multiplicity, etc.,

25 mostly derived from the LLS data, not only indicate the regional lightning activity but also constitute the input parameters for lightning risk assessment. The sensitivity correlates to site-specific lightning attractiveness, lightning protection capability and lightning attachment. These qualities are determined by the site conditions, including the existence of structures and the topography of the site. The sensitivity indicates which parts of a resident sub-district are relatively prone to lightning strike. The NDLE reflects lightning hazardousness, accounting for both regional lightning activity and sensitivity.

30 The CG stroke density, sensitivity and NLDEs are indicators critical for decision making in risk reduction, response to taking effective actions, e.g., erecting warning boards in high risk areas, installing lightning protection facilities in the domains susceptible to lightning, or even constructing a temporary structure serving as thunderstorm shelter in a public open field area. All will attain the goals of lightning risk management in a resident sub-district. 
Nat. Hazards Earth Syst. Sci. Discuss., doi:10.5194/nhess-2016-231, 2016

Manuscript under review for journal Nat. Hazards Earth Syst. Sci.

Published: 2 August 2016

(c) Author(s) 2016. CC-BY 3.0 License.

(c) (i)

\section{Acknowledgements}

This study has been supported by the National Natural Science Foundation of China (Project: 41175099) and the Beijing Natural Science Foundation of China (Project: 8142019).

\section{References}

Aman, A. A. and Bman, B. B.: The test article, J. Sci. Res., 12, 135-147, doi:10.1234/56789, 2015.

Aman, A. A., Cman, C., and Bman, B. B.: More test articles, J. Adv. Res., 35, 13-28, doi:10.2345/67890, 2014.

10 Ashley, W. S. and Gilson, C. W.: A reassessment of US lightning mortality, B. Am. Meteorol. Soc., 90: 1501-1518, 2009.

Bertram I and Mayr GJ (2004) Lightning in the eastern Alps 1993-1999, part I: Thunderstorm tracks, Nat. Hazards Earth Syst. Sci., 4, 501-511, doi:10.5194/nhess-4-501-2004, 2004.

Biagi, C. J., Cummins, K. L., Kehoe, K. E., and Krider, E. P.: National lightning detection network (NLDN) performance in southern Arizona, Texas, and Oklahoma in 2003-2004. J. Geophys. Res., 112, D05208, doi:10.1029/2006JD007341, 2007.

15 Bourscheidt, V., Pinto, Jr. O, Pinto, I. R. C. A., and Naccarato, K. P.: The influence of topography on the cloud-to-ground lightning density in South Brazil. Atmos. Res., 91: 508-513, 2009.

Bogdan, A., and Burcea, C.: A cloud-to-ground lightning climatology for Romania, Mon.Weather Rev., 138: 579-591, doi:10.1175/2009MWR2975.1, 2010.

Changnon, S. A.: Secular changes in thunder-day frequencies during the twentieth century. J. Geophys. Res., 90: 6181-6194, 1985.

Changnon, S. A.: Relationships between Thunderstorms and Cloud-to-Ground Lightning in the United States. J. Appl. Meteor., 32: 88-105, 1993.

Christian, H. J., Blakeslee, R. J., Boccippio, D. J., Boeck, W. L., Buechler, D. E., Driscoll, K. T., Goodman, S. J., Hall, J. M., Koshak, W. J., Mach, D., and Stewart, M. F.: Global frequency and distribution of lightning as observed from space by the 25 Optical Transient Detector, J. Geophys. Res., 108, 4005, doi:10.1029/2002JD002347, 2003.

Cummins, K. L., Murphy, J. M., Bardo, E. A., Hiscox, W. L., Pyle, B.R., and Pifer, A. E.: A Combined TOA/MDF Technology Upgrade of the U.S. National Lightning Detection Network. J. Geophys. Res., 103(D8), 9035-9044, 1998.

Cummins, K. L., Cramer, J. A., Biagi, C.J., Krider, E. P., Jerauld, J., Uman, M. A., and Rakov, V. A.: The U.S. National Lightning Detection Network: Post-upgrade status, presented at $2^{\text {nd }}$ Conf. on Meteorological Appl. of Lightning Data, AMS

30 Annual Meeting, Atlanta, available at: https://ams.confex.com/ams/pdfpapers/105142.pdf, last access: 31 January 2013, 2006. 
Nat. Hazards Earth Syst. Sci. Discuss., doi:10.5194/nhess-2016-231, 2016

Manuscript under review for journal Nat. Hazards Earth Syst. Sci.

Published: 2 August 2016

(C) Author(s) 2016. CC-BY 3.0 License.
Natural Hazards

and Earth System

Sciences

Discussions

(c) (i)

Cummins, K. L., and Murphy, J. M.: An overview of lightning locating systems: history, techniques, and data uses, with an in depth look at the US NLDN, IEEE T. Electromagn. C., 51: 499-518, 2009.

Curran, E. B., Holle, R. L., and Lopez, R. E.: Lightning casualties and damages in the United States from 1959 to 1994 , J. Climate, 13: 3448-3464, 2000.

5 Drüe, C., Hauf, T., Finke, U., Keyn, S., and Kreyer, O.: Comparison of a SAFIR lightning detection network in northern Germany to the operational BLIDS network. J. Geophy. Res., 112(D18114), doi:10.1029/2006JD007680, 2007.

Gabriel, K. R., and Changnon, S. A.: Temporal features in thunder days in the United States, Climatic Change, 15: 455-477, 1989.

Hu, H., Wang, J., and Pan, J.: The characteristics of lightning risk and zoning in Beijing simulated by a risk assessment 10 model. Nat. Hazards Earth Syst. Sci. , 14: 1985-2014. doi:10.5194/nhess-14-1985-2014, 2014.

Hu, H.: An Algorithm for Converting Weather Radar Data into GIS Polygons and its Application in Severe Weather Warning Systems. International Journal of Geography Information Science, 28(9): 1765-1780, 2014.

Hu, H: Spatiotemporal Characteristics of Rainstorm-Induced Hazards Modified by Urbanization in Beijing. J. Appl. Meteorol. Climatol., 54(7):1496-1509, 2015.

15 Holle, R. L., López, R. E., and Navarro, B. C.: Deaths, injuries, and damages from lightning in the United States in the 1890s in comparison with the 1990s, J. Appl. Meteorol., 44: 1563-1573, 2005.

Idone, V.P., Davis, D. A., Moore, P. K., Wang, Y, Henderson, R. W., Ries, M., and Jamason, P. F.: Performance evaluation of the U.S. National Lightning Detection Network in eastern New York; Part I: Detection efficiency. J. Geophys. Res., 103: 9045-9056, doi:10.1029/98JD00154, 1998.

20 IEC62305-2. The technical committee of the International Electrotechnical Commission: Protection against lightning, IEC, Geneva, Switzerland, 2010.

Kaplan, S. and Garrick, B. J.: On the quantitative definition of risk, Risk Anal., 1: 11-27, 1981.

Kar, S. K., Liou, Y. A.: Enhancement of cloud-to-ground lightning activity over Taipei, Taiwan in relation to urbanization. Atmos. Res., 147-148: 111-120, 2014.

25 Krider, E. P., Noggle, R. C., Pifer, A. E., and Vance, D. L.: Lightning Direction-Finding Systems for Forest Fire Detection.[J]. B. Am. Meteorol. Soc.,, 61(61): 980-986, 1980.

López, R. E., Holle, R. L.: Changes in the number of lightning deaths in the United States during the twentieth century. J. Climate, 11: 2070-2077, 1998.

Mäkelä, A., Tuomi, T. J., and Haapalainen, J.: A decade of high - latitude lightning location: Effects of the evolving location

30 network in Finland. J. Geophy. Res., 115(D21124), doi:10.1029/2009JD012183, 2010.

Mazarakis, N., Kotroni, V., Lagouvardos, K., and Argiriou, A. A.: Storms and Lightning Activity in Greece during the Warm Periods of 2003-06. J. Appl. Meteorol., 47: 3089-3098, 2008.

Mills, B., Unrau, D., Pentelow, L., and Spring, K: Assessment of lightning-related damage and disruption in Canada. Nat. Hazards, 52: 481-499. DOI 10.1007/s11069-009-9391-2, 2010. 
Nat. Hazards Earth Syst. Sci. Discuss., doi:10.5194/nhess-2016-231, 2016

Manuscript under review for journal Nat. Hazards Earth Syst. Sci.

Published: 2 August 2016

(C) Author(s) 2016. CC-BY 3.0 License.
Natural Hazards

and Earth System

Sciences

Discussions

\section{(c) (i)}

Naccarato, K. P., Pinto, Jr. O.: Improvements in the detection efficiency model for the Brazilian lightning detection network (BrasilDAT). Atmos. Res., 91: 546-563, 2009.

Petrov, N. I., and D'Alessandro, F.: Assessment of protection system positioning and models using observations of lightning strikes to structures, Proc. R. Soc. Lond. A, 458, 723-742. doi:10.1098/rspa.2001.0906, 2002.

5 Rakov, V. A., and Uman, M. A.: Some properties of negative cloud-to-ground lightning flashes versus stroke order. J. Geophys. Res., 95(D5): 5447-5453, 1990.

Rizk, F. A. M.: Modelling of lightning incidence to tall structures, part II, application, IEEE T. Power Deliver., 9: 172-193, 1994.

Rose, L. S., Stallins, J. A., and Bentley, M. L.: Concurrent cloud-to-ground lightning and precipitation enhancement in the

10 Atlanta, Georgia (United States), urban region, Earth Interact., 12, 1-30, doi:10.1175/2008EI265.1, 2008.

Rudlosky, S., and Fuelberg, H. E.: Pre- and Postupgrade Distributions of NLDN Reported Cloud-to-Ground Lightning Characteristics in the Contiguous United States. Mon. Wea. Rev., 138, 3623-3633, 2010.

Saraiva, A. C. V., Saba, M. M. F., Pinto, Jr. O., Cummins, K.L., Krider, E. P., and Campos, L. Z. S. A comparative study of negative cloud - to - ground lightning characteristics in São Paulo (Brazil) and Arizona (United States) based on high -

15 speed video observations. J. Geophy. Res. 115(D11102), doi:10.1029/2009JD012604, 2010.

Schulz, W., Cummins, K. L., Diendorfer, G., and Dorninger, M.: Cloud-to-ground lightning in Austria: A 10-year study using data from a lightning location system. J. Geophy. Res., 110: D09101. doi:10.1029/2004JD005332, 2005.

Schütte, T., Salka, O., and Israelsson, S.: The use of the Weibull distribution for thunderstorm parameters. J. Climate and Applied Meteorology, 26: 457-463, 1987.

20 Schütte, T., Cooray, V., and Israelsson, S.: Recalculation of lightning location system acceptance using a refined damping model. J. Atmos. Oceanic. Technol., 5: 375-380, 1988.

Shepherd, J. M., Pierce, H., and Negri, A. J. Rainfall modification by major urban areas: observations from spaceborne rain radar on the TRMM satellite, J. Appl. Meteorol., 41, 689-701, 2002.

Smith, K.: Environmental Hazards: Assessing Risk and Reducing Disaster, 2nd Edn., Routledge, New York, USA, 1996.

25 Stallins, J. A., Bentley, M. L., and Rose, L. S.: Cloud-to-ground flash patterns for Atlanta, Georgia (USA) from 1992 to 2003. Climate Res., 30, 99-112, 2006.

Stallins, J. A., and Rose, L. S.: Urban lightning: current research, methods, and the geographical perspective, Geography Compass, 2: 620-639, doi:10.1111/j.1749-8198.2008.00110.x, 2008.

Steiger, S. M., Orville, R. E., and Huffines, G.: Cloud-to-ground lightning characteristics over Houston, Texas: 1989-2000. J.

30 Geophys. Res., 107, 4117, doi:10.1029/2001JD001142, 2002.

Visacro, S., Vale, M. H. M., Correa, G., and Teixeira, A.: Early phase of lightning currents measured in a short tower associated with direct and nearby lightning strikes. J. Geophy. Res., 115(D16104), doi:10.1029/2010JD014097, 2010.

Vogt, B. J.: Exploring cloud-to-ground lightning earth highpoint attachment geography by peak current, Earth Interact., 15: $1-16,2011$. 
Nat. Hazards Earth Syst. Sci. Discuss., doi:10.5194/nhess-2016-231, 2016

Manuscript under review for journal Nat. Hazards Earth Syst. Sci.

Published: 2 August 2016

(c) Author(s) 2016. CC-BY 3.0 License.

(c) (i)

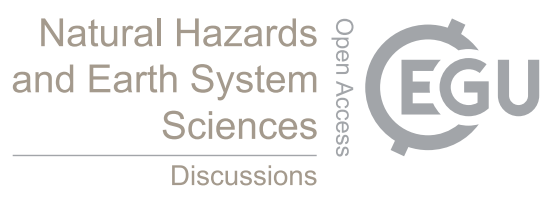

Warner, T., Helsdon, Jr. J. H., Bunkers, M. J., Saba, M. M. F., and Orville, R. E.: Upward Lightning Triggering Study. Bull. Amer. Meteor. Soc., 94(5): 631-635, 2013.

Wisdom, M. D.: Lightning fatalities in Swaziland: 2000-2007, Nat. Hazards, 50, 179-191, 2009.

Zhang, W., Meng, Q., Ma, M., and Zhang, Y.: Lightning casualties and damages in China from 1997 to 2009, Nat. Hazards, 5 57, 465-476, 2011.

Yao, W., Zhang, Y., Meng, Q., Wang, F., and Lu, W.: A Comparison of the Characteristics of Total and Cloud-to-Ground Lightning Activities in Hailstorms. Acta Meteor. Sinica, 27(2): 282-293, 2012. 
Nat. Hazards Earth Syst. Sci. Discuss., doi:10.5194/nhess-2016-231, 2016

Manuscript under review for journal Nat. Hazards Earth Syst. Sci.

Published: 2 August 2016

(c) Author(s) 2016. CC-BY 3.0 License.

(c) (i)
Natural Hazards and Earth System

Table 1. Estimating terrain factor of a structure accounting for its surrounding topography (defined by IEC62305-2, 2010)

\section{Description of the surrounding topography $C_{d}$}

Higher than the top of the structure

0.25

As high as the top of the structure

0.5

On flat ground

1

On the top of a hill

2

Table 2. The structure types corresponding to the lightning protective capability in Beijing

\begin{tabular}{lllc}
\hline \multicolumn{1}{c}{ Structure type } & GIS identity & \multicolumn{1}{c}{ Protection measures } & $\boldsymbol{p}_{\boldsymbol{a}}$ \\
\hline General building & 211 & $\begin{array}{l}\text { Iron infra-structure and framework as a lead-in wire in } \\
\text { structure. }\end{array}$ & $10^{-4}$ \\
\hline $\begin{array}{l}\text { general structure } \\
\text { with basement }\end{array}$ & 21109 & Same as above & $10^{-4}$ \\
\hline bunk house & 212 & Effective soil equipotentialization & $10^{-2}$ \\
\hline $\begin{array}{l}\text { bunk house with } \\
\text { basement }\end{array}$ & 21209 & Same as above & $10^{-2}$ \\
\hline bridge gallery & 218 & Electrical insulation of exposed down-conductor & $10^{-2}$ \\
\hline Special house & 229 & Iron infra-structure and framework as a lead-in wire in & $10^{-4}$ \\
& & structure & $10^{-4}$ \\
\hline $\begin{array}{l}\text { Special house with } \\
\text { basement }\end{array}$ & 22909 & Same as above & 1 \\
\hline Ruined house & 214 & Electrical insulation of exposed down-conductor & $10^{-3}$ \\
\hline Hut & 215 & No protection measures & 1 \\
\hline Public lavatory & 3551 & Same as above & \\
\hline
\end{tabular}


Nat. Hazards Earth Syst. Sci. Discuss., doi:10.5194/nhess-2016-231, 2016

Manuscript under review for journal Nat. Hazards Earth Syst. Sci.

Published: 2 August 2016

(c) Author(s) 2016. CC-BY 3.0 License.

(c) (1)

\section{Natural Hazards o \\ and Earth System \\ Sciences \\ Discussions}

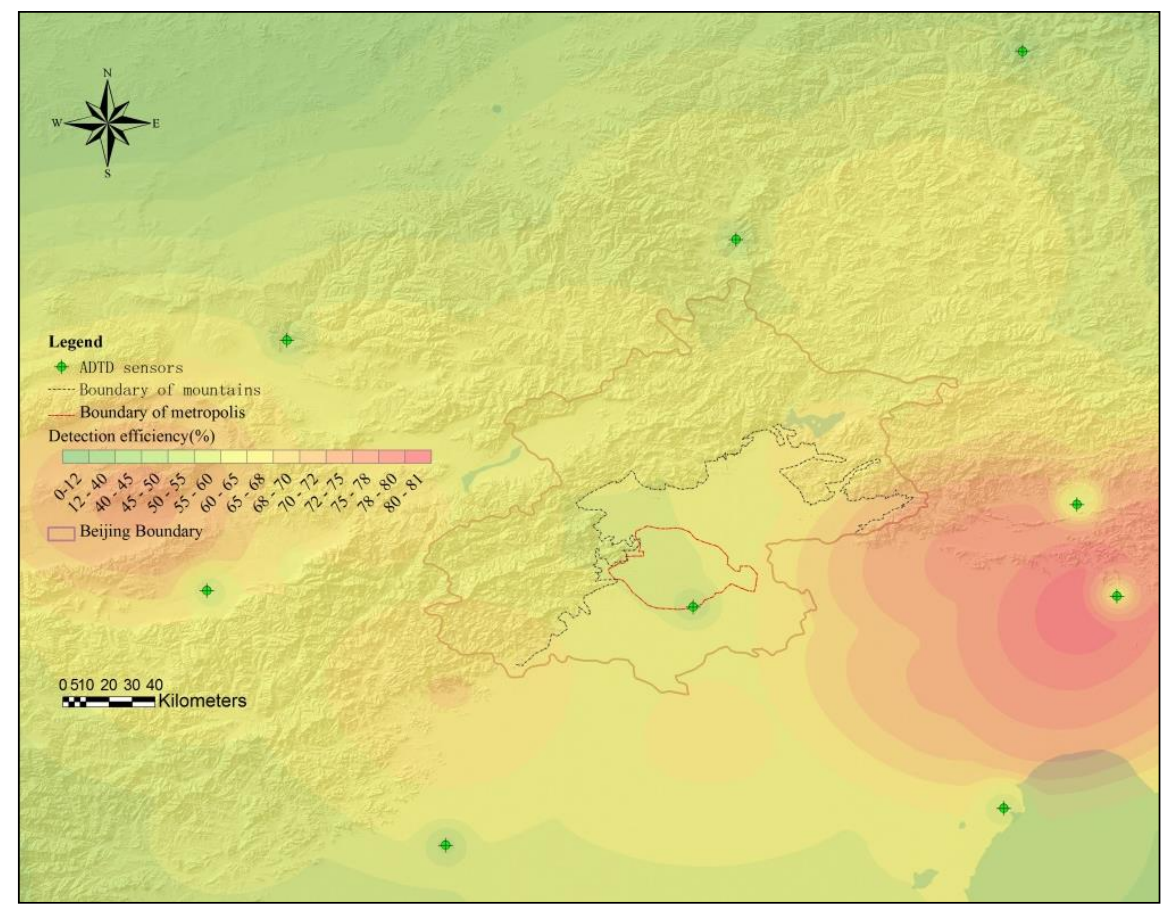

Figure 1 Distribution of the estimated network DEs and ADTD sensors around the Beijing district (enclosed by scarlet lines). The SDEs in Beijing metropolitan areas (red lines) are almost all above 55\% and are lower than those in the surrounding 5 areas, whereas the peak SDE zones located to the east of the metropolitan areas possess a maximum SDE of $81.1 \%$.

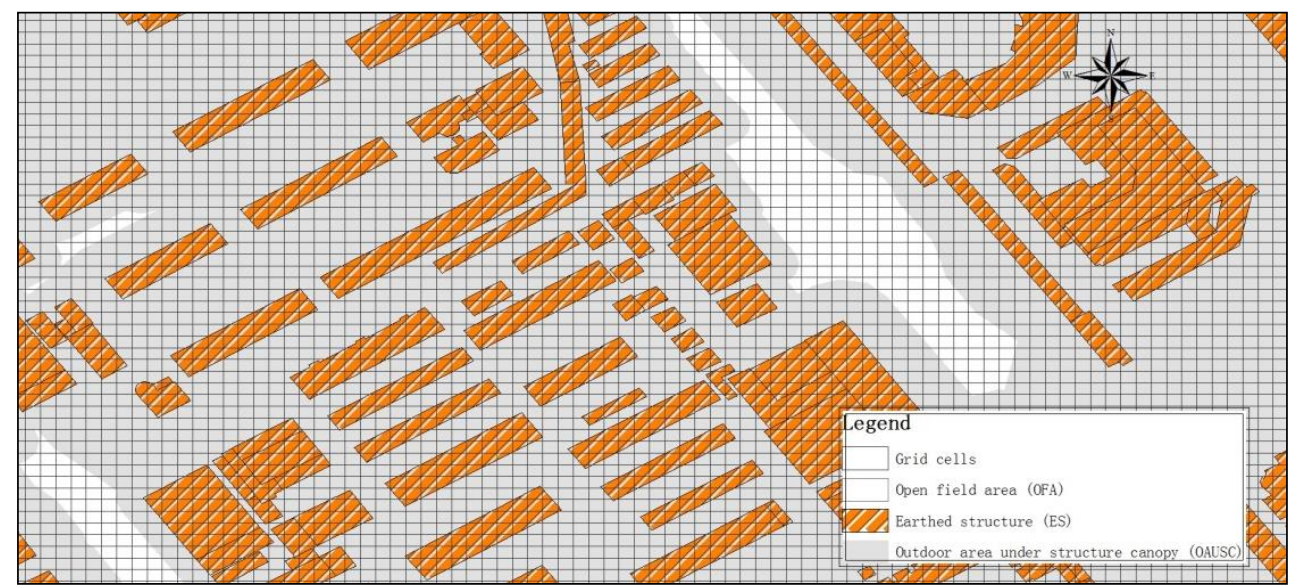

Figure 2 Sketch map illustrates three types of underlying ground area samples (i.e., earthed structure, outdoor area under structure canopy and open-field area) in a $5 \mathrm{~m}$ spaced grid displayed in GIS. 
Nat. Hazards Earth Syst. Sci. Discuss., doi:10.5194/nhess-2016-231, 2016

Manuscript under review for journal Nat. Hazards Earth Syst. Sci.

Published: 2 August 2016

(c) Author(s) 2016. CC-BY 3.0 License.

\section{(c) (1)}

\section{Natural Hazards and Earth System Sciences \\ Discussions}

(a)

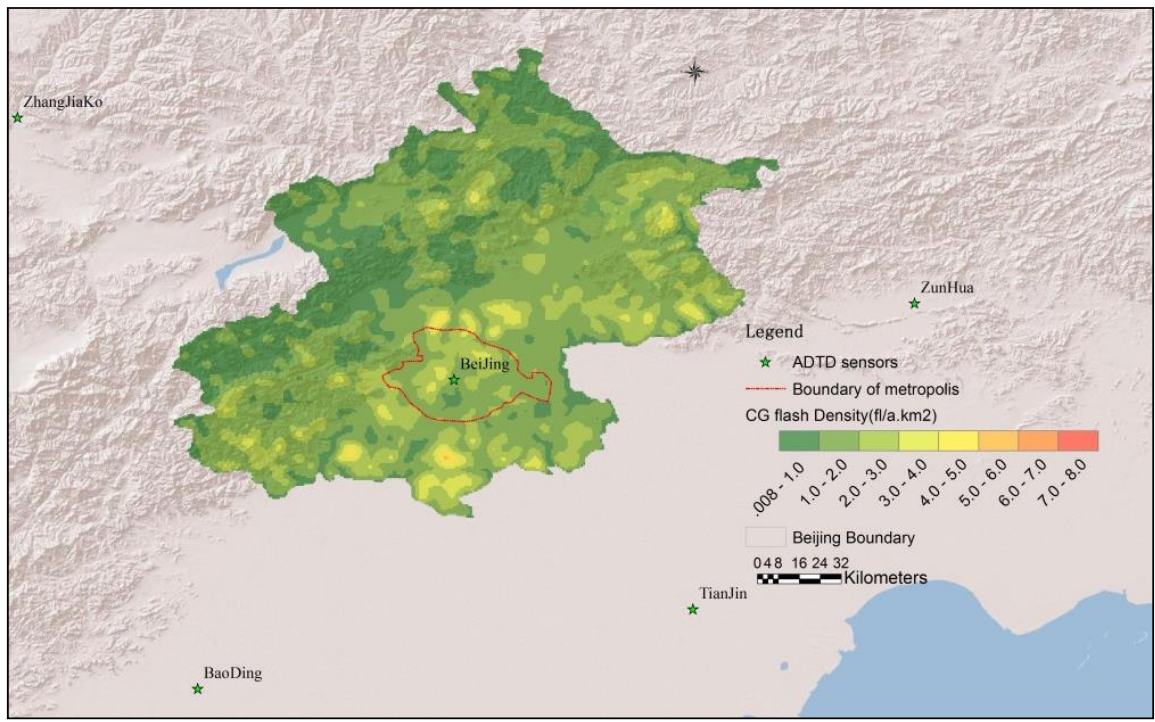

(b)

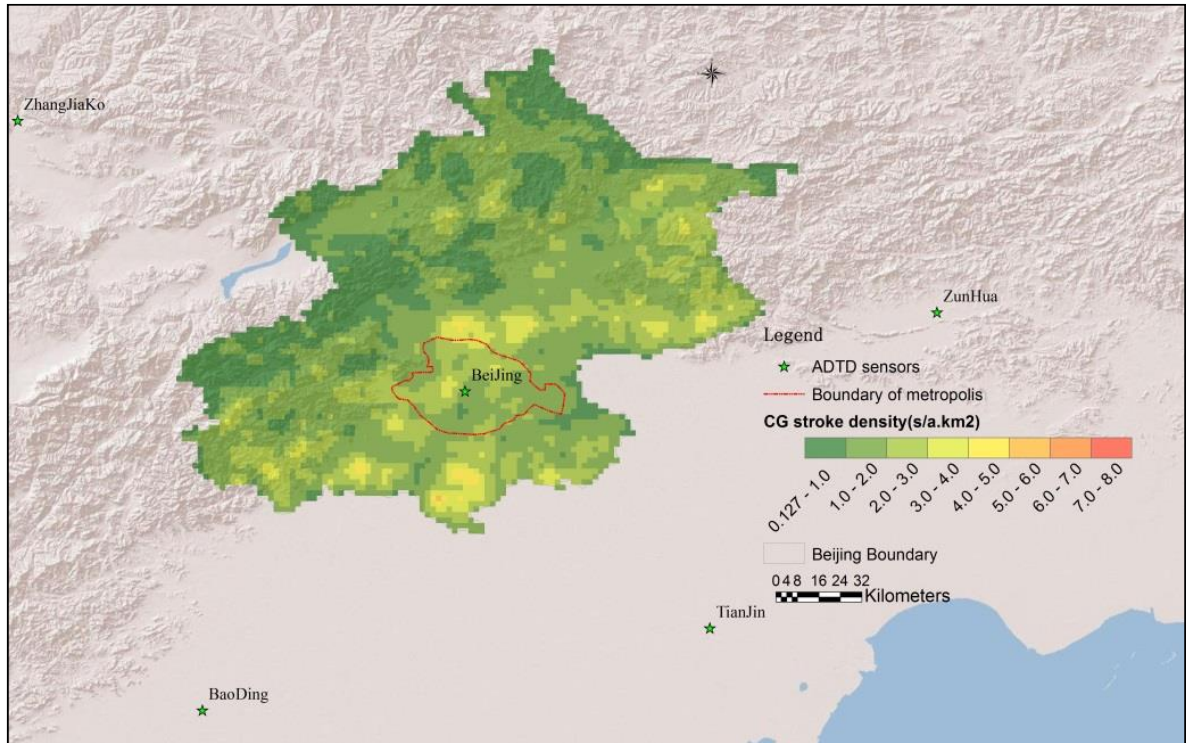


Nat. Hazards Earth Syst. Sci. Discuss., doi:10.5194/nhess-2016-231, 2016

Manuscript under review for journal Nat. Hazards Earth Syst. Sci.

Published: 2 August 2016

(c) Author(s) 2016. CC-BY 3.0 License.

\section{Natural Hazards and Earth System Sciences \\ Discussions}

(c) (1)

(c)

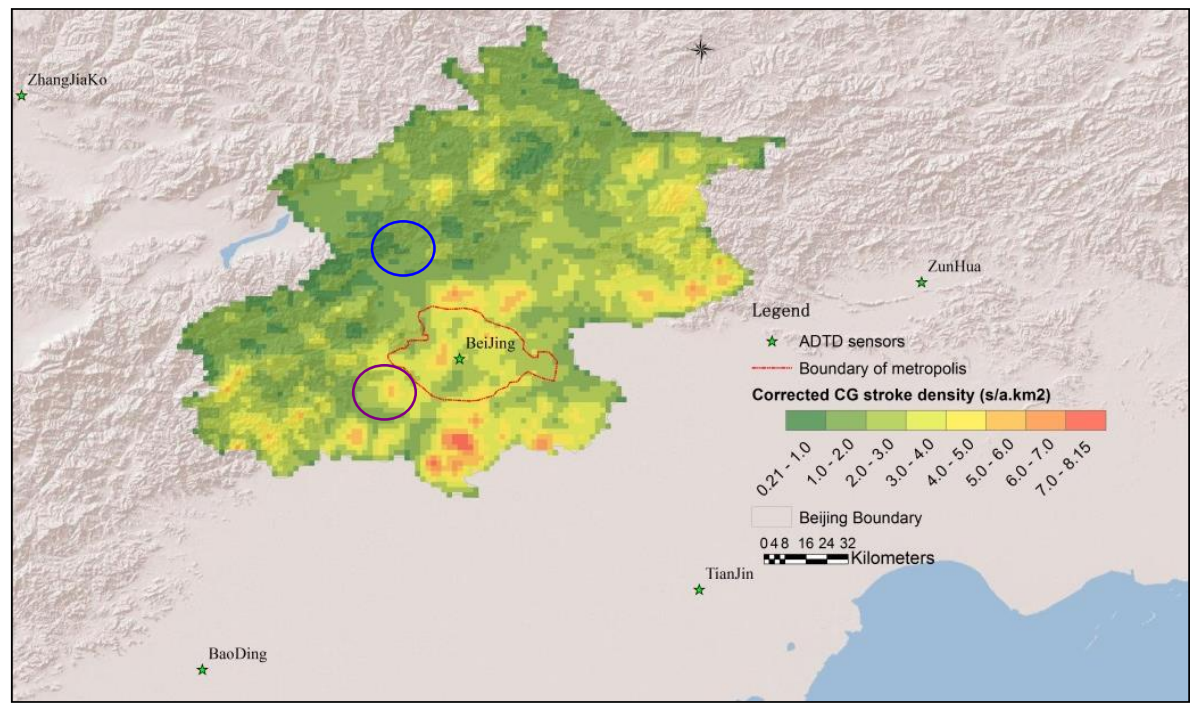

Figure 3 Distribution of (a) CG flash density (fl/yr. $\mathrm{km}^{2}$ ), (b) CG stroke density (stroke/yr.km²), and (c) corrected CG stroke density (stroke/yr. $\mathrm{km}^{2}$ ). For convenience, the same legends for contour and shading were used in the CG flash density, CG stroke density and corrected CG stroke density plots.

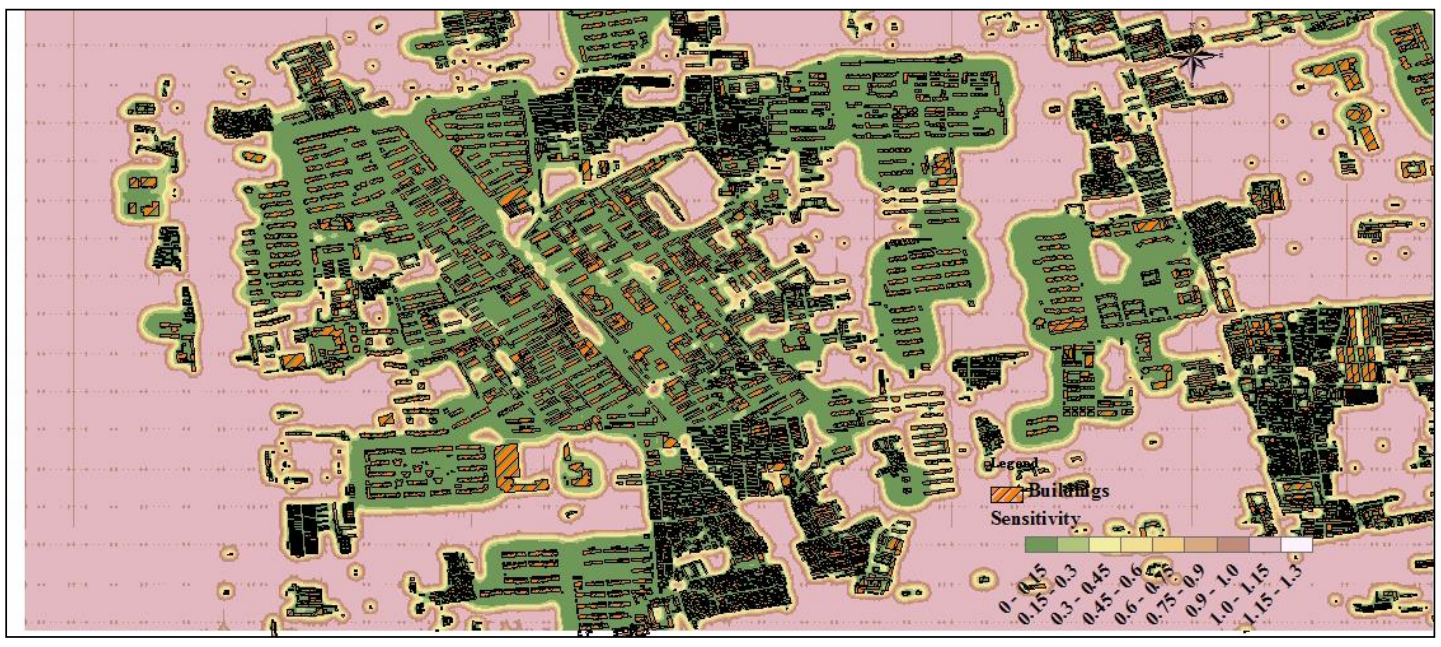


Nat. Hazards Earth Syst. Sci. Discuss., doi:10.5194/nhess-2016-231, 2016

Manuscript under review for journal Nat. Hazards Earth Syst. Sci.

Published: 2 August 2016

(c) Author(s) 2016. CC-BY 3.0 License.

\section{Natural Hazards \\ and Earth System \\ Sciences \\ Discussions}

(c) (1)

(b)

A

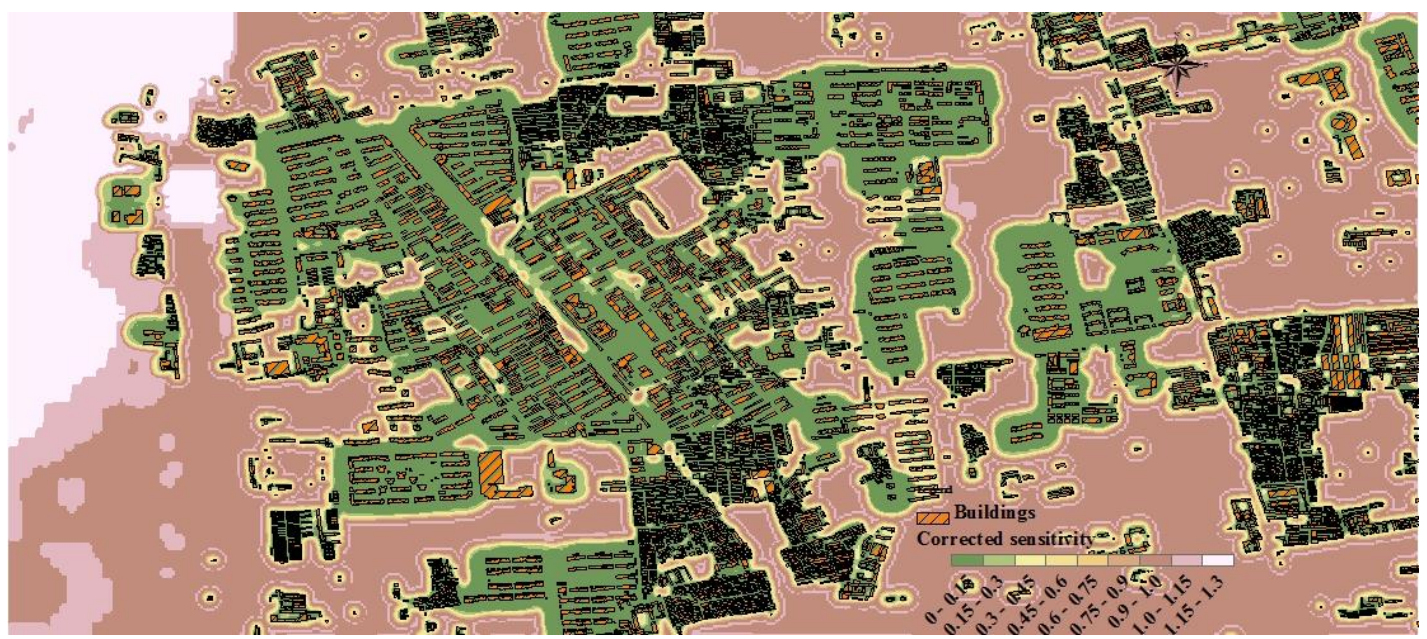

(c)

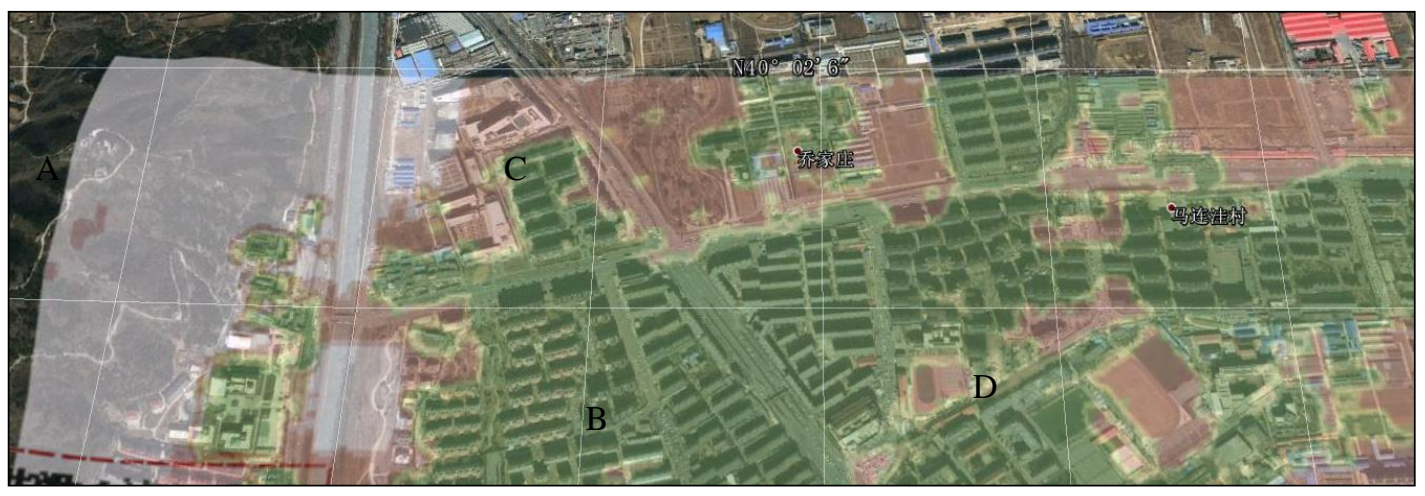

Figure 4 Sensitivity zones in the sub-district of Malianwa, in case of (a) not accounting for the terrain factor, (b) accounting for terrain factors, (c) and displayed in Google Earth; these zones correspond well with the distribution of underlying

5 structures and topographical features. For example, point $A$ in the mountainous areas exhibits a high sensitivity, $B$ in the dense structure areas exhibits a lower sensitivity on account of lightning rod effects produced by nearby structures, and $C$ in an open-field area exhibits a relatively high sensitivity. Interestingly, the sensitivity of point $D$ at an open sports field is obviously higher than that of its surrounding densely built-up areas. 
Nat. Hazards Earth Syst. Sci. Discuss., doi:10.5194/nhess-2016-231, 2016

Manuscript under review for journal Nat. Hazards Earth Syst. Sci.

Published: 2 August 2016

(c) Author(s) 2016. CC-BY 3.0 License.

\section{Natural Hazards \\ and Earth System \\ Sciences \\ Discussions}

(a)

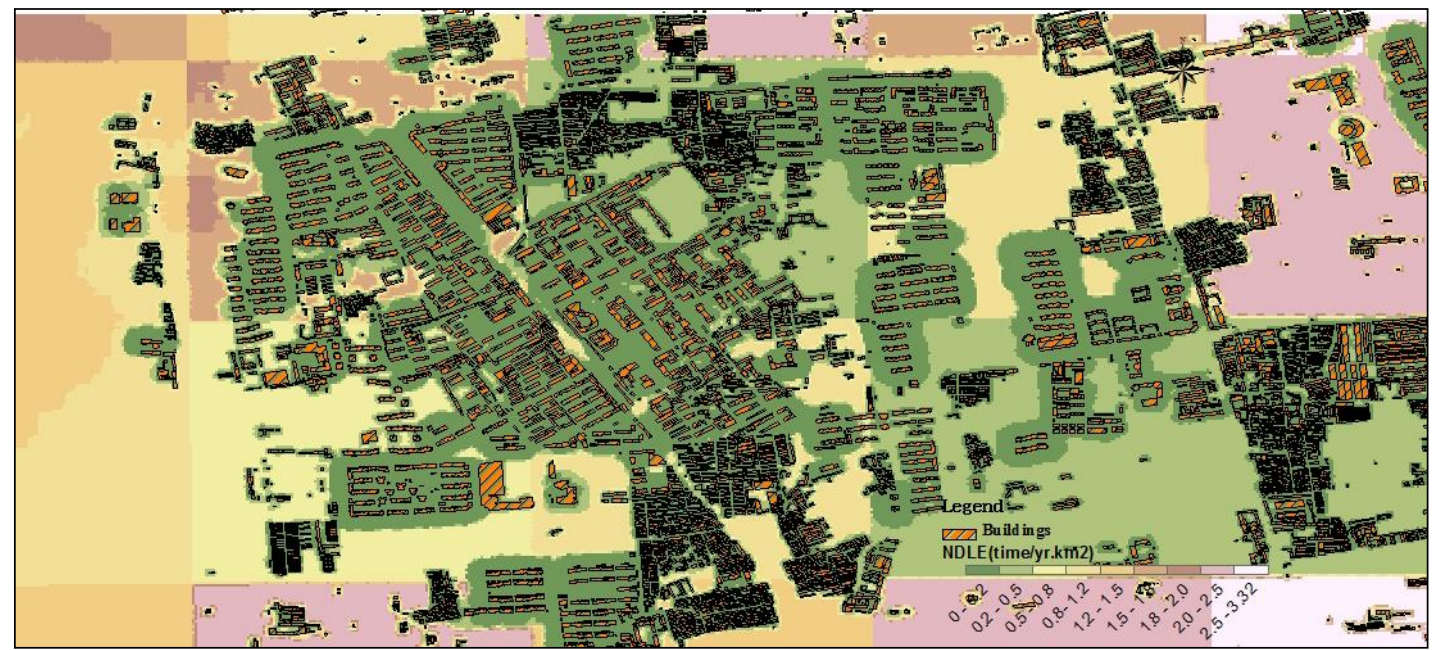

(b)

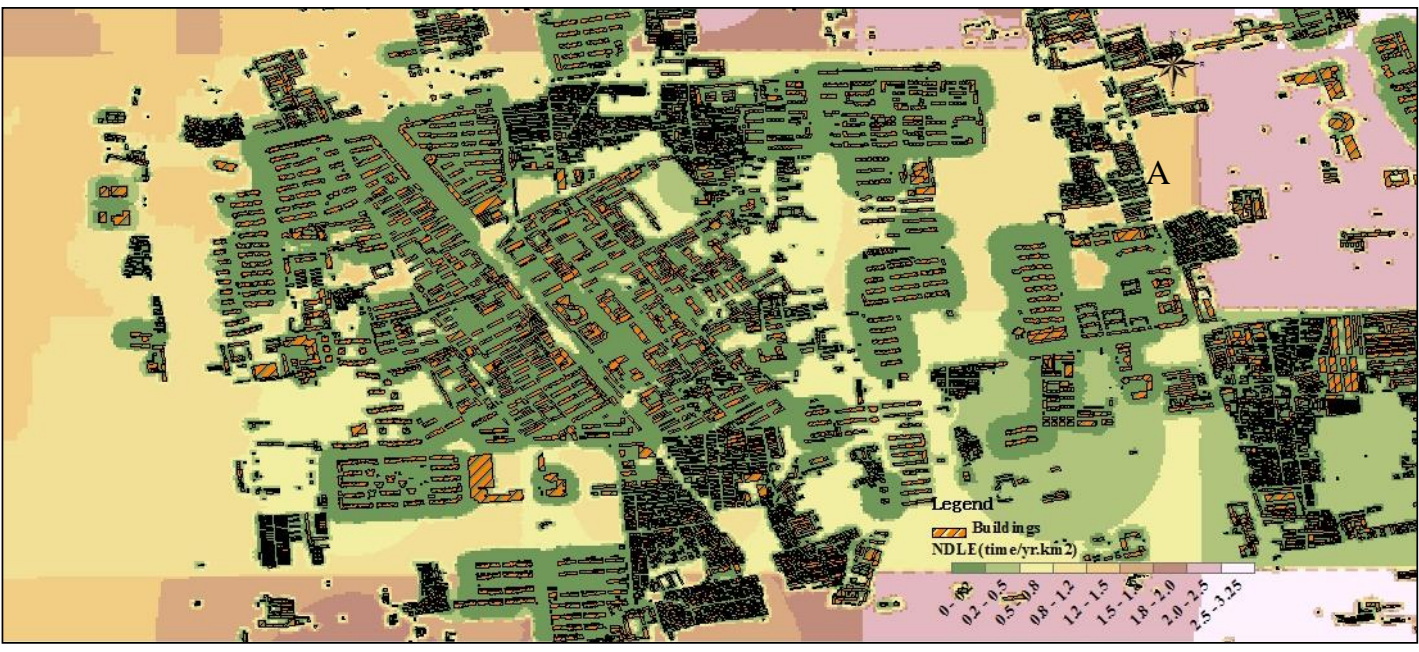

Fig. 5 NDLE zones in the sub-district of Malianwa, showing the lightning sensitivity overlapped with (a) the stroke density in $1 \mathrm{~km}$ resolution and (b) the interpolated stroke density. The open-field area at point $A$ exhibits a relatively high NDLE due 5 to its lack of protection against lightning. 
Nat. Hazards Earth Syst. Sci. Discuss., doi:10.5194/nhess-2016-231, 2016

Manuscript under review for journal Nat. Hazards Earth Syst. Sci.

Published: 2 August 2016

(c) Author(s) 2016. CC-BY 3.0 License.

\section{Natural Hazards and Earth System \\ Sciences \\ Discussions}

(c) (1)

(a)

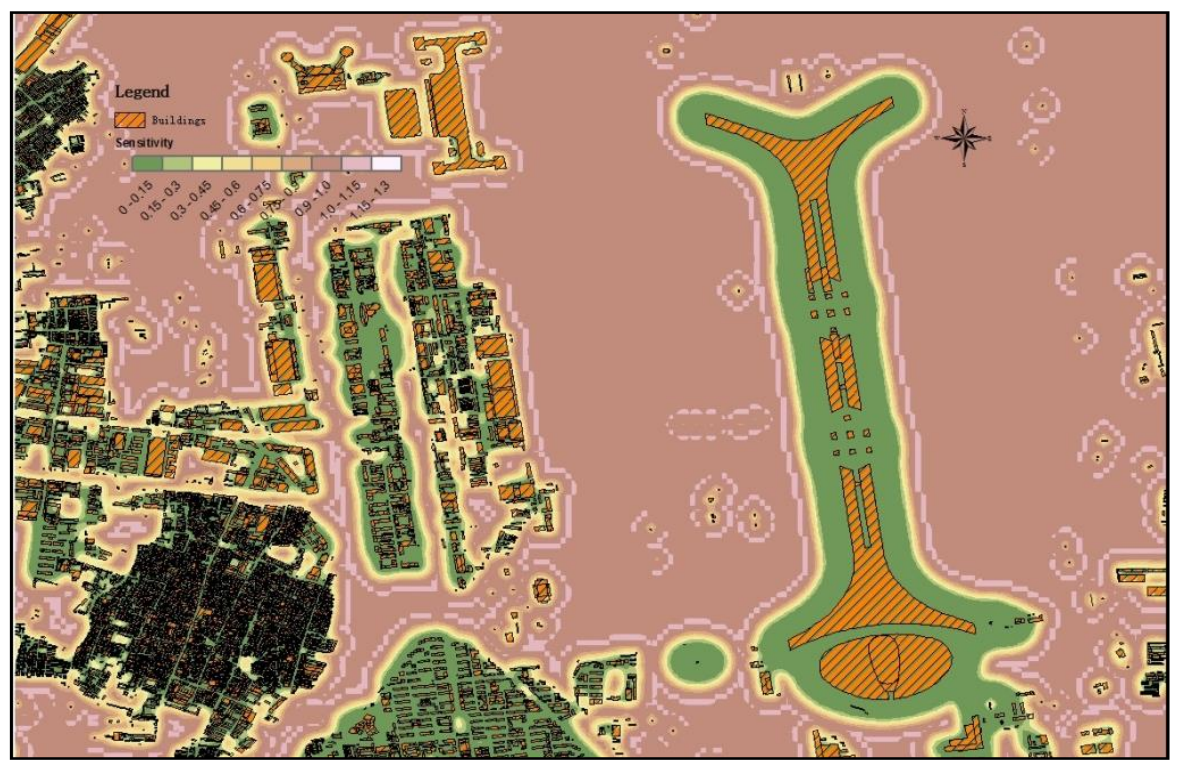

(b)

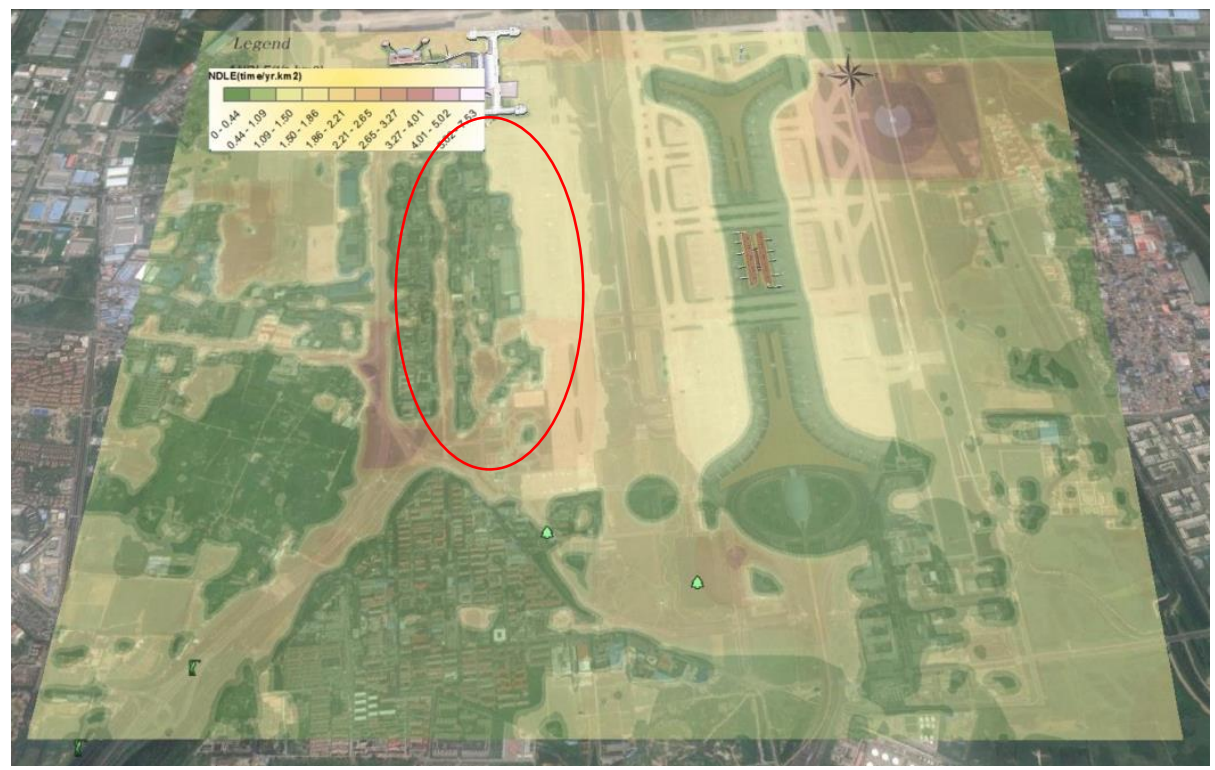

Fig. 6 Lightning risk assessment of (a) ground sensitivity to lightning and (b) NDLE (displayed in Google Earth) zones in the Beijing international airport. 